\title{
Construction of space identity: Socio-historical and political dialectics in the globalisation era
}

\author{
Konstruksi identitas ruang: Dialektika politiko dan sosio-historis dalam era \\ globalisasi
}

\author{
Siti Aminah \\ Department of Political Sciences, Faculty of Social and Political Sciences, Universitas Airlangga \\ Address: Jalan Dharmawangsa Dalam, Surabaya, East Java 60286 \\ E-mail: ami_unair@yahoo.com
}

\begin{abstract}
Every local government in Indonesia seeks to construct a space/place identity. Competition between identities becomes a key element in relation to recognition, differentiation, and commodification in the context of decentralisation's implementation. This article has studied Mojokerto's identity development as a part of the territorial administration system with regional autonomy. Policymakers designated Mojokerto as the host of Mojopahit House's identity. The geographical space of Mojokerto competes in terms of identity, which underwent another comparison and intense competition with other regions' identities. Why was Mojopahit House determined as the identity of Mojokerto by the government at the national, provincial, and municipal levels? Based on such a question, this paper employed the politico-spatial approach using the qualitative analysis method and interpretive approach. This study found that the policymakers viewed Mojopahit House as the most suitable symbol in the identity competition between regions and autonomous regions. It can be turned into a fundamental icon to project political value, economic value, and/or the place attributes. Mojopahit House has becomes a representative of the local-traditional, global, and political economy identity. To conclude, the development of space identity lies within heritage conservation policy and globalisation pressure.
\end{abstract}

Keywords: construction of identity; politico-spatial; globalisation; mojopahit house; identity representation

\begin{abstract}
Abstrak
Setiap pemerintah daerah di Indonesia berupaya untuk mengkonstruksi identitas tempat/ruang. Persaingan antaridentitas menjadi elemen kunci untuk pengakuan, diferensiasi, dan komodifikasi dalam konteks implementasi desentralisasi. Artikel ini mengambil studi kasus pembangunan identitas Mojokerto sebagai sistem administrasi teritorial yang memilki otonomi daerah. Para pembuat kebijakan menetapkan wilayah Mojokerto dengan identitas Rumah Mojopahit. Ruang geografi Mojokerto bersaing dalam hal identitas, yang kemudian mengalami perbandingan dan persaingan yang ketat dengan identitas wilayah dan tempat lain. Mengapa Rumah Mojopahit ditetapkan oleh pemerintah (pusat, Provinsi Jatim, dan Mojokerto) menjadi identitas tempat/wilayah Mojokerto? Atas dasar ini, tulisan ini menggunakan pendekatan politiko spasial. Metodenya menggunakan analisis kualitatif dengan pendekatan interpretif. Studi ini menunjukkan bahwa pengambil kebijakan memandang Rumah Mojopahit cocok dalam iklim persaingan representasi identitas antarwilayah dan antardaerah otonom sehingga dapat menjadi ikon fundamental untuk proyeksi nilai politik dan ekonomi dan/atau atribut tempat itu. Rumah Mojopahit menjadi identitas yang merepresentasi unsurunsur tradisional-lokal, unsur global, dan politik ekonomi. Kesimpulannya pembangunan identitas ruang berada dalam tataran kebijakan konservasi warisan dan tekanan globalisasi.
\end{abstract}

Kata kunci: konstruksi identitas; politik spasial; globalisasi; rumah mojopahit; representasi identitas

\section{Introduction}

No space identity constructs itself, as the space and identity themselves are all constructed through a series of political and historical synthesis about and within a certain region, space, and place. The construction of space/place identity in the globalisation era is not merely conducted for the sake of tourism promotion and offering economic value-added for a region, but it is also to position it as a representative of an existing and inherent space identity. The thickening of globalisation has affected 
the development of spatially-connected identities in which they were either preserved or overlooked. Contested and preserved identity depends on political, social-cultural, and economic considerations. Identity is constructed based on a space/place's morphology, such as its historical heritage, cultural heritage, and other inherent uniqueness which becomes the region's brand. Studies on space identity have attracted experts from various disciplines, such as Political Science, Sociology, Geography, and Anthropology.

Theorists of urban sociology and political geography, for example Castells (2010), Harvey (1989), and Sennett (1999), identified the effect of globalisation on the strengthening of space identity against internationalisation. In this context, examining the distinctiveness of a space/place in order to study the construction of identity is multidisciplinary in nature. According to Castell, identity was built on historical sources. He highlighted the tremendous role of Sociology and Anthropology scientists. However, in Indonesia, not only do the sociological and anthropological factors determine the construction of identity, but also so does the government's political interests at the national, provincial, and municipal level. Such an argument is derived from a notion that spatial commitment is developed as a response toward a space's distinctiveness and it is reflected from the experts' attitude and perception in building their own argumentation about the construction of spatial identity and its objectives. The experts' arguments can be classified into some specific perspectives based on their respective disciplines. Hence, to explain and understand the meaning of government-constructed identity, many perspectives can be employed. This article itself employs the politico-spatial identity, which is integrated with the socio-spatial perspective.

Studies on space identity were introduced by Lefebvre (1974) and later developed by Fairbanks (2003), Boisen (2011), Kalandides (2011), Vela (2013), and many others. The experts were keen to study space identity in terms of spatial, geographical, anthropological, sociological, and political analyses. Actually, some scientists have suggested devoting their attention to the role of branding which becomes a space/place identity in certain regions/local areas. As Zenker \& Jacobsen (2015) pointed out, numerous scientists from different disciplines need to study about the construction of space identity, both as a branding or an image-construction effort. Although some scientists continue to argue about the construction of identity and its branding's meaning, by studying space identity, they can contribute to the enrichment of the theoretical framework. It is a necessary method to reveal the relationship between the strategic spatial approach and the construction of space identity.

Lefebvre, with his socio-spatial perspective, learned how identity is always correlated to space existence and space ideology. His study on urban space identity in the 1950s and 1960s showed that space ideology should have not been removed or eliminated by urban city planners or architects, because modernised cities have actually owned their standardised architecture and efficient urban plans. However, the thickening of globalisation has affected inter-region competition. Identity has become the most important element in recognition, differentiation, and commodification in the communication process in which cities, regions, and countries position themselves. Hence, both government and society should seek a clear formulation for their space identity.

The current situation already indicates fierce competition for geographical space. Competition for identity is embodied in the construction of identity attached to a region's branding. The construction of identity ideally serves to integrate the infinite number of cultural and ideological heritage which is inherent in the region's space and place, both geographically and practically. The space is full of political and socio-historical dynamics. Thus, the space identity of the geographical region represents the power and importance of the government and society.

The main argument of this article is related to the identity construction of Mojopahit House in Mojokerto as a practice of identity construction in an inter-regional competition over resources, markets, opportunities, and concerns of the people and state. This argument aims to corroborate the theses of Lefebvre, Manuel Castells, de San Eugenio, Vela and other experts. Space identity is an important issue which is close to the question of survival. It is not merely related to economic terms, but rather, it is related to the need to promote identity during globalisation amidst increasing 
inter-regional rivalry and interest rates all over the world. Mojopahit House was chosen as the study object because it is one of the most representative identities in terms of geography, place, spatial, and cultural aspects in Indonesia.

Mojopahit House is a result of innovation from various parties. The sixth president of Indonesia, Susilo Bambang Yudhoyono, proposed to select a historical icon for Mojokerto in accordance with its heritage. It is a necessary step amidst the intense competition of inter-regional identity, both within the country and with other countries. The construction of the Mojopahit House identity got around the challenge of identity in the globalisation era, because in constructing the identity, policymakers have integrated political and socio-historical elements. Branding and identity for spaces in the globalisation era integrate the conservation or preservation of cultural heritage programs and historical sites. This kind of construction occurs in almost every major city in the world. It indicates that globalisation affects the rise of heritage conservation efforts to preserve historic meaning of a certain place in a region which is aiming for sustainable economic growth and strengthening their national cultural identity. Such projects have occurred in Singapore (Yuen 2005), Taiwan (Wang 2015), Beijing (Zhang \& Zhao 2009), Bangladesh (Pap 2014), European cities, and Indonesian cities.

This article reveals that the identity construction for Mojopahit House indicates an integration of politico-spatial and socio-cultural ideology. It means that Mojokerto's represents the interest of its government (ruler) who employs (neo)liberal economy. It implies that Mojopahit house is not merely a brand of Mojokerto, but also a reminder to the public about Mojokerto's history as Mojopahit's capital in the $13^{\text {th }}$ century. In constructing the identity, the government paid serious attention to synthesising the past ideology of Mojopahit Kingdom with current identity (politico-spatial). To conclude, this kind of space identity construction plays a significant role as a historical-politicalsocial dialectic.

These two things reinforce the previous arguments proposed by Ashworth \& Kavaratzis (2010). They highlighted the image-construction process of a brand which goes beyond communication and promotion strategies. When the government constructs an identity, there is an effort to involve detailed planning and spatial planning to influence the physical manifestation and appearance of the place, so that the place's image is coherent with the government's ideology. Kavaratzis \& Kalandides (2015) posited that the practice of identity construction in relation to being a brand has a participatory function from the various parties who give meaning to the place identity in accordance with their respective interpretations.

Although Kavaratzis \& Kalandides (2015) did not share a similar view to Lefebvre, Lefebvre's socio-spatial perspectives reinforced their arguments in explaining the construction of identity in Mojokerto. The government strongly upholds modernism and globalism/neoliberalism, yet spatial ideology is maintained instead of being eliminated by urban space planners and architects when the government builds a cityscape. Globalisation and modernism are well-attached to place identity in this era. Moreover, Lefebvre's arguments actually reinforced the argument for the identity establishment of Mojokerto as a space. Mojopahit House contains dialectics and syntheses from past ideologies, modernisation, and globalisation. The linkage of these three ideologies has become an icon, while Mojokerto's brand itself is a synthesis between globalisation, modernisation, and local values. The idea of globalisation is firmly attached to Mojopahit House as a space identity in a certain geographical area, constructed as a physically ornate house during the Mojopahit era, and adapted to present conditions.

Lefebvre maintained that ideological factors need to be included in urban spatial analysis. However, spatial analysis becomes irrelevant if urban space planners merely understand it as a system of meaning to spatial realities and a product of political strategy which represents the needs and aspirations of the ruling class. Every space contains a certain ideology and within the ideology, a space becomes a core of the ideological struggle of the ruling class. Lefebvre studied social geography in which ideology and representation are integral parts of the territory. In this case, Lefebvre was inspired by Marx's 
ideas and started to develop his idea in the 1960s. He focused on the analysis that space representation is a socially-constructed concept. Lefebvre understood that ideology is always associated with other ideologies in spatial studies. It is evidenced in his analysis, which placed ideological consistency within the production and reproduction of social space. Ideology is seen of as the supporters of a rulers' will and myths which crystallise in a place. For example, monument-like buildings. Monuments may lose their original meaning from time to time along with a shift in understanding, in relation to the prevailing spatial ideology which conforms to the ruling regime. Furthermore, Lefebvre reiterated that space cannot be a timeless ideology without any reference to the existence of space and space ideology, as each space contains technological aspects.

Castells (1997) emphasised that space identity is a dynamic fact that takes the form of and alters the influence of a city's natural environment and physical elements, as well as the social factors. An urban identity becomes the most readable for a city space where the natural and social characteristics are reflected. Urban design (spatial planning by architects and government) is a means to establish a city space, as well as to formulate, change, and reproduce its urban identity. Urban design works primarily for the physical characteristics of an urban space. However, the physical features of urban space cannot be separated from its socio-cultural, political, and economic aspects. City structure and an environmentally-aware society are required for spatial planning. In this case, the implication of urban design is on the concentrated urban identity which basically lies on two factors. Firstly, space identity is an implication of the urban physical features which shall be built in accordance with urban identity's design. A harmony between urban space production, natural physical elements, and urban image creates an integration which enables urban identity to be sustainable and becomes a positive effect for urban identity.

Space or place identity cannot be simply understood as a way to brand a space/place for people to remember and give it meaning. As Boisen (2011) and Kalandides (2011) pointed out, identity is a paradoxical concept, because it is created to create a brand (branding). Kavaratzis \& Hatch (2013) argued correctly that the need to formulate a concept for space identity is by combining change, continuity, unity, and heterogeneity aspects. Weichhart et al. (2006) distinguished three types of place identity, namely identification from, identified as, and identified with. The first refers to the way that other people (groups or individuals) understand and recognise the places, because they assign certain characteristics and specificities. The second (identified as), in an inverse way, refers to the way that people (group and individuals) are associated with their place of origin, residential area, and so on. Lastly, the third one (identified with) follows a phenomenological tradition which seeks to explore the connection between humans and their respective dwelling places. It refers to the way that people identify themselves with their dwelling places and to connect it with their own identity construction.

Cresswell (2004) posited that the current conceptualisation about place summarises transformation and change ideas. In this regard, conceptualisation about place could never end; rather, it refers to an ongoing process and practice. The problem lies in why Mojopahit House is branded as Mojokerto's identity by the government. Is such an identity aimed at restoring the geographical authenticity of Mojokerto as the former capital of the Mojopahit Kingdom? This study aims to investigate the impact of globalisation on the construction of Mojokerto's space identity. The writer proposes a qualitative hypothesis, in that Mojopahit House's constructed identity is designated to restore the ideological power of historic value, which has gradually dissolved due to the onslaught of modernisation and globalisation. The second hypothesis is that Mojopahit House is considered relevant by policymakers as a place identity which is constructed to link political-economy, spatial, and cultural aspects.

\section{Research Method}

The study employed a qualitative approach using a socio-spatial and political perspective, because a study on space identity requires a strong political scope. Space identity is determined through a political process in which various actors participate in decision-making. The actors are not only from the government, but also scientists and academicians from various disciplines, such as identity, 
spatial planning, history, urban planning, regional planning, regional economy, cultural experts, and many others. Some in-depth interviews were conducted with the informants to collect data about Mojopahit House's identity. The main consideration underlying this study about Mojopahit House was because Mojokerto, in the $13^{\text {th }}$ century, was the capital of a large empire. The empire built a number of temples, which were later preserved by the government. The wealth possessed by Mojokerto, especially in the Trowulan District, has a strong historical basis and value, so the government turned the historical power of Mojokerto into cultural heritage. Mojokerto is viewed as a region which has preserved its cultural and historical heritage.

This study employed a politico-spatial perspective to re-read the efforts of the government in constructing the place identity of Mojokerto. This perspective put space or place at the centre of the analysis to explain the presence or absence of spatial changes, especially related to its space identity.

The data was collected in two ways. The primary data was collected through interviews with some of the research informants, including the government (Public Works Service/Cipta Karya, Bina Marga, Bappeda of Spatial Planning and Community). All of the data from the informants was analysed in accordance with what was understood by the research subjects. The data was analysed under a theoretical framework which had been prepared before the interview. Semi-structured interviews were also employed in this study. It employed a systematic question guide which grew along with the discussion during each in-depth interview. Moreover, this study also conducted a site observation on the existing cultural heritage in Mojokerto. The observation results were narrated and analysed in accordance with the perspective and theoretical framework.

Furthermore, the data was processed using a qualitative analysis technique, which required interview transcription. In this stage of the analysis, the alignment and discernment of understandings and opinions among the policymakers was conducted. The policymakers played their respective roles in constructing the identity of Mojopahit House. The interpretive method in this research was based on Space and Place Theory, as well as the concept of space identity which was integrated with the sociospatial and politico-spatial perspectives.

\section{Results and Discussion}

The concept of identity is often associated with the concept of language, culture, minority/majority, differences, self, individuality, and a sense of belonging. Proshansky (1978) defined place identity as multiple self-dimensions which identify individual identity with their physical environment in a complex pattern associated with conscious and subconscious ideas, beliefs, preferences, feelings, values, goals, behavioural trends and skills relevant to the environment. Kymas (2010) argued that place identity is an important dimension of social and cultural life in urban areas and a continuity of it highly depends on place attachment and a sense of belonging. Sense of belonging is highly essential to build an emotional and cognitive attachment to a certain place. Such feelings lead to a sense of security and communality. Hence, place identity is more than just physical appearance. It also involves "meaning" for individuals and communities.

The term of place identity has duality in its meaning. In terms of space planning and design, place identity is generally related to the place itself. It refers to the uniqueness of a place as a result of the interaction between physical features and its users. For instance, Stobbelaar \& Pedroli (2011) used landscape identity to define the perceived uniqueness of a place. In addition, they asserted that having both personal and social dimensions and uniqueness depends on the interaction between the physical environment and social factors.

Sepe (2010) posited about a close connection between urbanisation and globalisation. These two phenomena affect the social, economic, cultural, and physical environment in people's daily lives. In the context of globalisation, there are unavoidable global concerns about environmental sustainability. It cannot be underestimated, because it is related to many aspects such as water, air, energy, and transportation which fortunately generates attention. In comparison, urban identity rarely gets attention. 
Space identity built in an area shall heed to the buildings' heritage (spatial history) and include symbolic meanings for both local residents and visitors. Both locals and visitors often notice and understand significant historical events associated with place identity. The buildings and city structures tell past stories, their meaning and the cultural values involved. Therefore, heritage is constructed under the assumption that urban identity's indicators are different; heritage conservation is constructed as the main concern in relation to the sustainability of urban identity. Of course, it is not possible and reasonable to protect each building and structure of an old city. Moreover, it is impossible to turn each historical site into the space/place identity of a certain region.

Place identity is mostly formed through a series of syntheses of cultural and political elements. This study uses the case of Mojopahit House, which became the icon of Mojokerto. The goal is to explain and understand that the construction of identity is a political project involving multiple stakeholders. Mojopahit House is interesting due to the involvement of multiple stakeholders, including governments, communities, and investors, who had a common interest to preserve past identities and to turn them into contemporary identities. It also indicates that identity is always tailored to the needs of a certain era.

In the modernisation era, place identity sometimes solely exists as a city brand. For instance, Bogor the City of Rain, Bandung the City of Flowers, Surabaya the City of Heroes, and so forth. However, in the globalisation era, place identity does not merely refer to the distinctiveness of a city compared to other cities, but there is an added commercial value to it. Such distinctiveness produces past identities with political and socio-historical values. Past identities are produced to contest with other places in the world. It distinguishes the construction of the identity in the modernisation and globalisation era.

The place identity of a certain region should be different from others. The construction of it cannot be separated from capitalisation and commodification, as well as political process. Each place with its distinct identity can carry out its own political economy function. Mojopahit House's identity is similar to place identities all over the world, which is injected based on economic values and succumbs to the exchange rate. This phenomenon is identified as commodification in Marxian terms. Since the globalisation era started, selecting an identity becomes a contested issue. Mojokerto and other autonomous regions attempt to find their respective distinct formula for their region's identity. These things are important to determine a marketable icon and brand for the region.

To explain and answer such a question, the author employed a politico-spatial perspective coupled with place identity theory. The spatial perspective positions space as the centre of the analysis to explain the particular spatiality in which the political, economic, and cultural dimensions are embedded in. In essence, the politico-spatial perspective is useful for constructing space identity in a particular geographical area where space identity is seen of as a result of politics' and socio-historical construction and takes form as a political project involving many stakeholders.

How was the space identity of Mojokerto, as a geographical region of Mojokerto, constructed and understood by its community and constructors? In principle, no space constructs itself, because such a space is constructed through a series of synthesis of political and socio-historical aspects. This aspect refers to identity's role as a source of meaning which reminds people of history. Place identity is an important issue and becomes a crucial political economy. Selecting a place identity is considered necessary in order to promote an authentic regional identity in the globalisation era. Along with the increasing competition between regions to promote tourism, the effort becomes incomplete and imperfect without selecting a certain traditional and historical brand. Therefore, identity construction is never wholesome, completely new and perfunctory, but rather, it is a synthesis of diverse differences which unite space, time, and identity.

Place identity conceptually refers to the specific meaning and uniqueness of a place. Cresswell (2004) defined place identity by incorporating idea transformation's aspects and change. He posited that place identity can never be fully constructed, because it is the result of an ongoing process and 
everyday practice. A bond between place and identity can affect social formation, cultural practice, and political action. It can be seen, for example, in the efforts undertaken by Mojokerto government to establish place identity by revitalising authentic traditional identity which flaunts the glory of the Mojopahit Empire. This traditional identity is globally known as an icon and brand of Mojokerto.

Each local government creates an identity which not only has economic value, but also contains memorable value for the public. Putting brand development weighted on the interpretation of the socio-cultural significance of Mojokerto with its historical sites becomes a valuable experience to realise and harmonise the existing elements to be remembered by the public. It opens up a new path to start and manage the identity construction of the other places in Mojokerto in order for them to be distinctive and unique.

Urban conservation aims to restructure and reorganise the surrounding environment which is either on the brink of extinction or is already damaged. However, there is a trend that its practice is only conducted to maintain the urban landscapes' standards and their morphology. It does not contribute to the construction of place identity at all, although place identity tends to be related to city morphology. This trend also appears in the construction of Mojokerto's identity. The temples, which have been declared as heritage sites, are examples of spaces/places embedded with historical values and values related to the people living around them. Therefore, the existing spaces are considered to have an important role in the process of forming, changing, and reproducing urban identity. Currently, urban identities are quickly dissolving, or even being damaged. Thus, a city sometimes does not have any identity. The Trowulan District of Mojokerto itself was the capital city of an ancient kingdom and is now being rebuilt by reproducing villages and/or buildings in which the nuances and architecture are made similar to the ones in the Mojopahit era.

Understanding space is important, because within it, identity exists. The need to create, build, and preserve identity is necessary, given a shift in the importance of space in the modern era. Lefebvre's theories can also be traced in developing countries like Indonesia, where spaces are densely populated in most regions. Such conditions have given birth to Lefebvre's idea of the political economy of space, because densely-populated space creates an idea of scarcity (political and economic resources). Urban planners tend to view that urban space is purely a scientific and apolitical object while Lefebvre (1991) argued that spaces are shaped by historical and natural elements through political processes. He wanted to prove that "social space is not merely a socialized space." He argued that it is previously non-existent and non-socialised as a natural space, but that it is reproduced by social forces. Lefebvre's analysis aimed to explain two hypotheses. First, is to position space and at the same time, to position it within social theory analysis. In this context, spatiality is as important as analysing both history and current issues at the same time, because space transcends place and time. Second, Lefebvre aimed to employ a new understanding to examine how space is produced as a social formation (production mode) and as a mental coaching method (conception of place identity). Employing his hypotheses, we can see the utmost effort of East Java provincial government and the local government to rebuild Mojokerto's identity. The re-establishment of Mojopahit kampong, though it is not yet fully completed, has now produced architectural shape and models resembling the ancient buildings in the Mojopahit era. The re-establishment effort has spread to several village settlements in Bejijong, Sentonorejo, and Jatipasar in the Trowulan District.

Mojopahit House as the place identity and icon of Mojokerto reflects the identity of the region and society, as well as the government's vision and expectations over the years. The construction of place identity in Mojokerto revolves around strengthening the existing historical identity of one district, Trowulan. The whole embedded identity of Trowulan as the capital of the Mojopahit Kingdom in the $13^{\text {th }}$ century is being reproduced socially. The project involves urban planners, architects, the public and the government at the national, provincial, and municipal level. In reproducing the space, the government determines the place identity which is different from other cities in Indonesia. Trowulan is then reformed as a new space with a newly attached identity which is constructed through a series of dialectical process and follows the logic of market economy. The logic of market economy itself 
follows the logic of the spatial practices of the society, government, and market economy actors who sell identity as a commodity with an economic value. The government and economic actors then join hands to build place identity and to turn it into an icon of Mojokerto.

The effort of identity construction has been conducted since 2014, supported by the East Java provincial government who has tried to improve tourism in the region by re-establishing a kampong with ancient nuances from the Mojopahit era. The house's shape and model imitates the ancient houses of the kingdom era. There have been no less than 296 houses built in 3 villages, namely Bejijong, Sentonorejo, and Jatipasar in Trowulan District (Detik.com 2016). Cultural heritage in Bejijong Village was constructed into a Mojopahit-themed village by the government. It symbolically represented the real ancient village as in the ancient era and was epitomised as the current identity. Identity itself is a multifaceted phenomenon encompassing various human attributes, including language, religion, nationality, ethnic, and a common interpretation of their ancient past. It is built upon inclusive and exclusive discourse formed by those who have fulfilled certain membership criteria and those who do not. It refers to the categorisation of process and knowledge, so that the community is defined as it is and so that their ways are specific and different.

The idea to design Mojopahit House came from a proposal from Cultural Heritage Preservation Hall (BPCB), Trowulan. "We are asked for design idea by Mojokerto regency. There are three data sources, namely the Negarakertagama script, temple reliefs, and the discovery of ancient artefacts," said the Head of Protection, Development, and Utilisation of BPCB Trowulan (Detik.com 2016). The reliefs depicting the form of Mojopahit House in the past were found in several temples, namely Minak Jinggo Temple in Trowulan, Jago Temple in Malang, Jawi Temple in Pasuruan, and Penataran Temple in Blitar. Based on Minak Jinggo Temple, the spatial pattern of Majapahit housing was surrounded by fences. The settlement consisted of several houses confined to the fenced-walls. The research data also showed that the shape of Majapahit House resembled a pavilion (pendopo). It was an open building with even-numbered wooden poles, such as 4,6 , or 8 . The house floors were made of river stone which was covered with red bricks, while the roof was a pyramid shape and made of wood. The designs of Majapahit House in Bejijong, Jatipasar and Sentonorejo were slightly different from $B P C B$ Trowulan's proposal. The buildings were closed, the walls were composed of naturallooking red bricks, and the house foundation was made up of one metre of stone. The current house was widened by adding two wooden doors and two windows on the left and right side of the building.

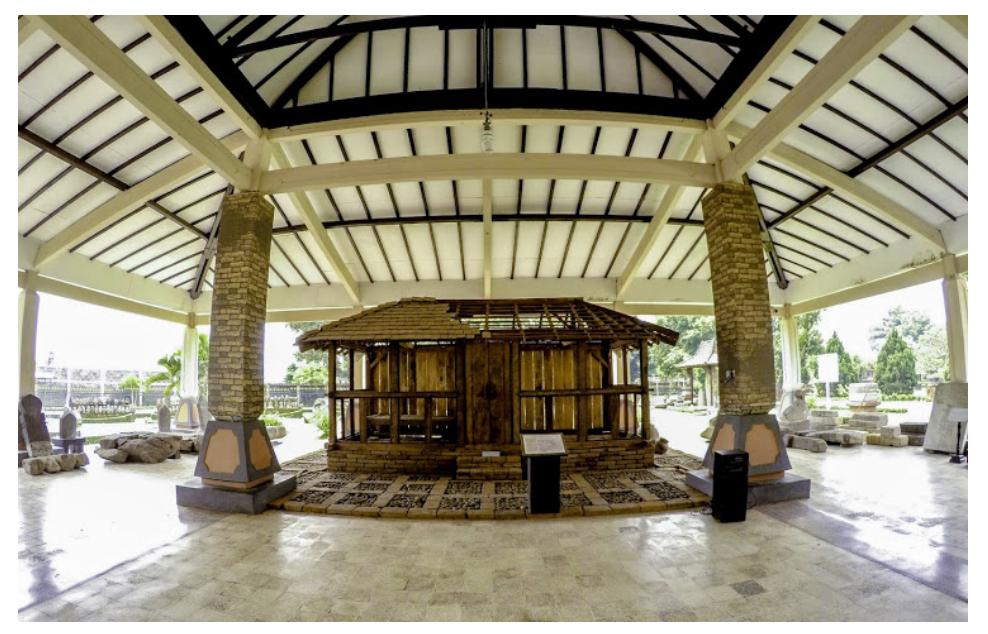

Figure 1.

The design of Mojopahit House

Source: Banyuwangi.org

Similar efforts were also attempted by the Singaporean government. Singapore's identity was constructed as a city where "East meets West" and where ancient traditions blend with modernity (Yuen 2005). The search for Mojokerto's identity and economic pragmatism through product 
development to gain a competitive advantage has become a strong reason to instigate historical heritage conservation. Both factors put more emphasis on the implementation of heritage conservation in region development. It means that the construction and selection of identity leads to political and economic interest. What the Singapore government did was similar to that of the Indonesian government. In the project to construct Mojokerto's identity, the government incorporated a set of identity features, along with the continuous construction of physical space to resemble its condition in the $13^{\text {th }}$ century. The physical network and space structure of Mojokerto are still considered, which means that the physical network allows for visual perception to recognise Mojokerto's identity as a region.

The strong determination of the central and local government to construct Mojokerto's identity with Mojopahit house as the focus proves their seriousness in thinking about globalisation's ongoing impact. The authentic identity of Mojokerto cannot be dissolved or replaced by general and socioculturally meaningless images. The government's need to preserve (the conservation function) historical heritage is based around Mojokerto's morphology. The identity planning process focuses on the balance between two things: a) the need for new identity development for the sake of Mojokerto's position in East Java as a tourist destination and b) the need to preserve the historical and cultural heritage associated with protected sites.

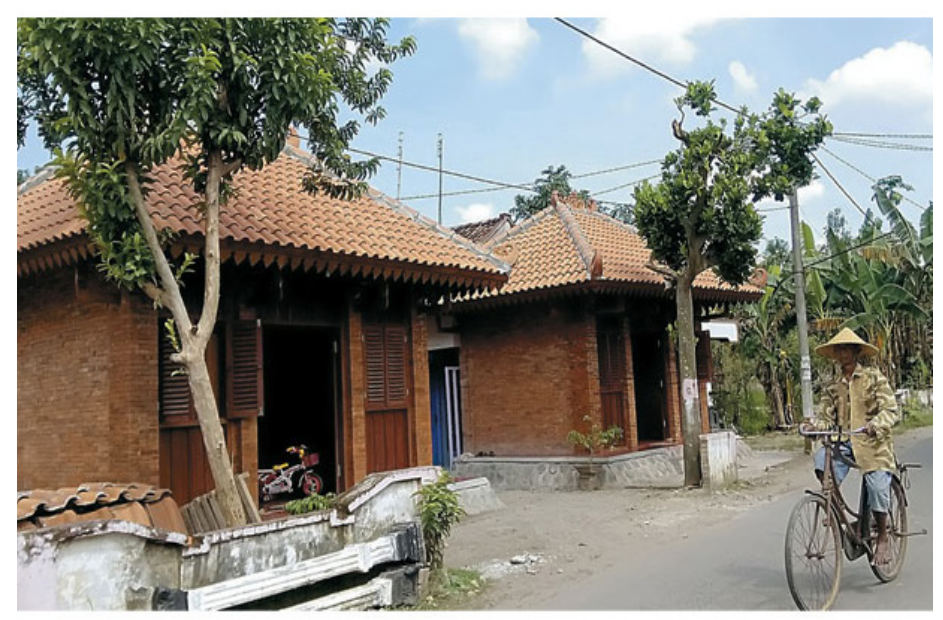

Figure 2.

Mojopahit House in Bejijong Village

Source: Sindonews.com (https://nasional.sindonews.com/read/1014482/149/rumah-majapahitakan-ditambah-1434684497. (Accessed on May 29 ${ }^{\text {th }}, 2016$ )

Constructing place identity in the globalisation era is not easy. Many countries in the world are competing to construct an identity to be the feature of a region. Singapore as a world city is an example. Yuen's (2005) study findings proved that the Singaporean government did not only build the Singapore brand as a future world city, but it also strengthened its cultural heritage which is attached strongly to icons as part of Singapore's place identity. Conversely, Pap (2014) understood that the identity construction of Budapest was based on its past cultural heritage. He argued that past identity is reproduced to strengthen current identity in the context of urban politics. Such an identity is reflected in the practice of strategy and settlement development. The past identity of Budapest contributed to the strengthening of local identity as evidenced by the connection between cultural heritage and local identity. Through his research, Pap observed three residential areas in Budapest whose houses imitated the relics of their cultural heritage. The areas were also selected because they represented the cultural heritage of Budapest.

In contrast to Pap, Prajnawrdhi, Karuppannan, \& Sivam (2014) studied the Balinese government's efforts to preserve their cultural heritage. Development in Bali solely aims to preserve Balinese culture. Meanwhile, Rémi Wei-Chou Wang (2015) examined the historical heritage of Taiwan. He examined 
how the nation-state tried to deal with its complex history after World War II. It was revealed that the Taiwanese government has been trying to build its identity by turning various historical monuments into an ideological representation of identity, which is also a pragmatic step to protect its historical and cultural heritage. Hereby, we can conclude that place identity is a representation and reflection of ideology. Space identity created by historical heritage sites is a key element in the production and reproduction process of power relations (Graham, Ashworth \& Tunbridge 2000).

The concept of historical (local) heritage is related to the way in which societies use their past as a social, political, and economic resource. Historical or cultural heritage is open for interpretation by anyone. Sometimes the difference in the understanding and interpretation of the historical sites can cause division in society. A study focused on this was conducted by Graham, Ashworth, and Tunbridge (2000). The findings of their study revealed that division caused by different interpretations of culture for economic purposes potentially led to a conflict of interest. Consequently, identity construction cannot consider or assume economic aspects (e.g. merely for tourism purposes without considering other factors) alone. Both government and society should synthesise political, social, economic and cultural objectives.

However, their study resulted in a different finding from that of David Harvey's study about city as a centre of political discontent. Mojokerto did not become an area of inter-class conflict, but rather become a political, economic, social, and cultural space. Reconstruction of Mojopahit House can remind people of what the houses were like during the Mojopahit era. The physical structure of a space is built in accordance with the identity of Mojokerto, which is widely known to be rich in historical sites. The project also plays a part in producing urban identity which is aligned with physical structure and city image. It allows for the sustainability of identity (past, present and future) and ultimately, forms a new identity. Another important factor is creating an urban identity which is relevant to the city's social aspects.

Bejijong Village, Trowulan District, is one of the residential areas which have changed appearance since 2015. In the next stage of the plan in 2016, as many as 300 units of houses will be built in three locations, namely Segaran, Temple Mouse, and Bajang Temple Queen. In order to construct these Mojopahit-styled Houses, the government has set a budget of IDR 50-60 million for houses with a size of $3 \times 5$ meters or $4 \times 4$ meters. The house budget was derived from the Provincial Budgeting Plan, while the fence construction funds were derived from the Mojokerto Budgeting Plan. To implement such changes, district government plays a significant role. Physical and social changes, which are created in urban spaces through urban design, have completely changed the space identity of the district.

The general characteristics of urban space were recently produced in Bejijong Village, Trowulan District. The historical context, or more importantly, the contributor of identity that shall be spontaneously eliminated, and other factors shall surely be employed to enhance identity. The form of identity is defined according to the meaning of the identity format derived from the varied contents. This content is influenced by the existing basic architecture, art, and urbanism. There is a relationship between shape and content. According to the history of cultural needs, there are three necessary steps to find future-oriented solutions to solve matters related to urban identity. First, is recognising the identity factor within Mojokerto's history. Second, is assessing the current situation (where should Mojokerto be led to from now onwards) and calculating the estimated time that it needs to reach the desired position as a city of heritage tourism. Third, is seeking the solution to achieving identity in the process of establishing Mojokerto as the centre of heritage tourism (promoting identity). The consequences of globalisation trigger the emergence of cultural heritage conservation as a need to preserve the past, both in terms of sustainable economic growth and to strengthen national cultural identity. The government sees the need to create a sense of belonging in order to establish collective memories among current society members.

The construction of identity which is centralised in Bejijong Village, Trowulan District, was conducted in the form of changing public settlements. As the initiator, the government chose the 
identity of Mojopahit House to be adopted as Mojokerto's identity. Physical and social changes were conducted in the spaces formally belong to Mojopahit Empire. The adaptation was initiated by making fences and government offices, then proceeding to build rows of houses. Mojopahit House in Trowulan area was the attribute of Mojopahit Kingdom, created through design language and as a design object within the space. The urban space of Trowulan is the sample area of this study which aims to seek iconic reference with the Mojopahit Empire. Trowulan, with all of these characteristics, has acquired a different identity from other sub-districts, both in Mojokerto and Indonesia.

At the centre of Trowulan, there is an identity that once belonged to Mojopahit kingdom. The identity was embedded in the form of historical buildings, temples, and sites, which now have become cultural heritage sites and signify the uniqueness of Trowulan identity. Changing building functions in the Rowulan area were not conducted by the government, except those which were badly damaged like Brahu Temple. The existence of Mojopahit-styled buildings combined with modern architecture can be seen of as a new element of urbanism and a requirement to change place identity.

A positive, strong space identity and image can be a strong competitive asset and a tool for the city to use to seize an opportunity in the increasingly global competitive marketplace. The heads of regional government in the globalisation era are challenged to build an urban identity or city branding to distinguish their cities from other cities. Urban identity is often used as a brand which makes the city developed and well-known. According to Lefebvre, space is produced and reproduced as a result of social, political, and economic struggles. History, traditions, local lifestyles, art, and intangible elements of cultural heritage shape a certain environment, vernacular architecture, and cultural landscape. It's an important point which shapes the collective memory of intangible cultural categories among people and it is a method of communication for future generations. Lynch (1960) defined identity as a person's ability to recognise and/or remember a place distinctive from other places.

Mojopahit House became an icon and brand which refers to the way that the government and the community are preserving ancient sites and artefacts in Mojokerto. It can also be interpreted as a way for the government and society to control Mojokerto's identity using its past identity, which was formed way before the independence of Indonesia. Cultural heritage management is regulated under Local Regulation No.9 Year 2012 in the Spatial Plan of Mojokerto Regency. Year 2012-2032. There is a dispute between the Preservation Heritage Conservation Body (BPCB) of Trowulan with a brick company that produces the red bricks used to preserve cultural heritage in Trowulan. In preserving the cultural heritage, some actors play a significant role, namely $B P C B$ Trowulan, the Regional Development Planning Agency (Bappeda), the Department of Youth, Sports, Culture and Tourism of Mojokerto, and the House of Representative of Mojokerto. Law no. 2 of 1992 on Heritage Objects, in the Act on Cultural Heritage No. 11 Year 2010 classified Cultural Reservation as Heritage Buildings, Heritage Buildings, Cultural Heritage Structure, Heritage Sites, and Heritage Areas. Cultural Heritage Objects in Law No. 11 of 2010 are mentioned as being a natural object and/or man-made object, whether mobile or immobile, grouped or in parts, with its remnants having a close relationship with culture and the history of human development. Cultural heritage building refers to constructed arrangements made of natural or man-made objects to meet the needs of walled and/or non-walled and roofed rooms.

The construction of the Mojopahit House identity is entirely based on cultural heritage and the region's history. The space identity of Mojokerto is a process of power construction that started from the Mojopahit Kingdom whose conquered areas encompassed various regions in Indonesia. One of its many heritage manifestations in Trowulan is Wringin Lawang arch in Jatipasar Village. It is made of red brick, 15.5-meters high, and was approximately built in the 14th century AD. Its architecture style is similar to Candi Bentar, so many experts speculate that this building was a gateway to Gajah Mada's residence. Meanwhile, Bajang Ratu archway was probably built in the 14th century as one of the greatest arches during the golden age of Mojopahit. According to the records of the Preservation Agency of Archaeological Heritage Mojokerto, this temple was an entrance to a sacred building to commemorate the death of King Jayanegara, who, according to Negarakertagama, returned to the 
world of Vishnu in 1250 Saka (circa 1328 AD). Prior to the King's death, the temple was used as the rear door of the kingdom. According to Gede Bagus Arnawa (1998), based on its shape, the temple was built in the paduraksa (roofed gateway structure) style.

Therefore, identity should be distinct and obvious at first glance, as well as creating a strong image in people's minds even though they have not seen it before. Identity should always be exclusive and not reproducible. Each city has a unique identity, which consists of images and memories, either negative or positive. The city image consists of urban elements, such as monumental buildings, public spaces, and other special features. When discussing city image from the perspective of city branding, it should be noted that currently many cities try to promote themselves using iconic artefacts. From a general point of view, city branding is primarily based on three main attributes: image, uniqueness, and authenticity. Almost every city has a city branding agenda to rebuild their image (Kavaratzis 2007). Branding, mainly developed from marketing strategy, is more commonly used to market and promote the city as a product. Kotler even argued that a place is a product whose identity and value must be designed and marketed as a saleable product. According to Ashworth, one of the goals of city branding is to discover or create uniqueness, which makes the city distinct from others. Kavaratzis \& Hatch (2013) affirmed that the identity construction process is complex, because determining identity is conducted through a dialogue between multiple stakeholders for the purpose of region branding.

Region's brand combines cultural heritage and history, economic growth and social development, infrastructure and architecture, landscape and environment. This combination becomes a marketable identity which is acceptable for everyone. Harvey (1989) stated that the impact of life quality in the process of accumulating capital lies in the promotion of a place and marketing as a part of the city's efforts to forge a distinctive image and atmosphere to lure in capital and influential people. We can see how much effort has been put forward by the Provincial Government of East Java and Mojokerto to build and strengthen the identity of Mojokerto. The establishment of Mojopahit-styled settlements in three villages (Bejijong, Sentonorejo, and Jatipasar), though they have not yet been completed, aim to recreate the ancient settlements in Mojopahit era to strengthen Mojokerto's image. The Head of Tourism and Culture in Mojokerto affirmed that, "the development of identity for Mojokerto needs to be accomplished in order to improve the competitiveness of the city through brand image and city marketing." This explanation is in line with the strong desire of East Java provincial government to conserve cultural treasures of Mojopahit's royal heritage.

One of the research respondents in Bejijong Village displayed his/her unawareness about the intention behind the house construction in Mojopahit style, because the house was used to open a small business to earn money. S/he said, "The government allows me to open a business in this house. There are neighbours who opened a coffee shop and small grocery stores. No one used the house as a home stay for tourists though".

The budget to construct houses in the Mojopahit style is taken from the East Java Provincial Budget $(A P B D)$ in order to restore Mojopahit culture and to turn it into cultural heritage. In addition, they also want to turn it into a cultural tourism destination. Besides building houses, the government also wants to attempt to restore temples in Bajang Ratu, Tikus, and other heritage sites. These heritage sites are then embedded in the identity of Mojokerto. Place identity is considered an incomprehensible and paradoxical concept (Kalandides 2011). The place identity of a place should be distinct from other places. To distinguish one region from another, regional developers, politicians, and urban planners are increasingly focused on building a region as a brand (Zenker \& Jacobsen 2015). The city government is challenged to construct a certain identity. Identity is necessarily constructed by considering eternal, strong, interesting, relevant, and competitive values. Following the logic of Harvey (1989), world cities in the globalisation era are mostly neoliberal cities. Hence, surely, there is a strong correlation between cities with a strong and reputable image focused on attracting and sustaining investment, employers, students, visitors, professionals, and organisations. A space identity in a positive, strong, and imaginable territory can be a strong competitive asset and a tool for cities/regions to promote themselves and for them to be more competitive in global marketplace. 
This effort has been done by the government in Mojokerto to construct the city's identity so then it is aligned with the architectural design of Mojopahit kingdom. This identity is derived from a rare resource, because its uniqueness is not owned by other regions in Indonesia.

Mojokerto's identity does not merely lay in the construction of Mojopahit House, which is sold through media and promoted by the Tourism Office, but it also contains the ideological pragmatism of the government to turn Mojokerto into an interactive place which accommodates the interests of the population, including history, culture, and economy. Hence, within such an identity, Mojopahit's architectural style is absorbed and reproduced, then combined with the current development. The houses were designed with the architecture of Mojopahit Kingdom in mind, so that the inhabitants and tourists feel as if they are experiencing the ancient era. The houses were also adapted to the characteristics of government-protected cultural sites, namely Wringin Lawang, Bajang Ratu Temple, and Kedaton. In addition, the fences of the citizens' houses were adapted to the model of Wringin Lawang Arch.

\section{Conclusion}

The construction of space identity for Mojopahit House in Mojokerto is a strategic decision as the hegemonic project of a neoliberal municipal government. Based on the construction process of Mojopahit House, such an identity is considered to be well-suited for all parties' interests in the municipal region. Employing politico-spatial strategy, the local government legitimately accommodates the uniqueness of historical sites in Mojokerto. Mojopahit House's identity successfully connects local wisdom and heritage to competitive global climate nowadays. Space identity solidifies space existence in the region, as well as signifying a process of space capitalism. Mojokerto manages to build space identity geographically and politico-spatially by highlighting the themes and brands of identities which contain both historic and economic value.

This study reinforces politico-spatial theorists in explaining that the production and reproduction of space requires identity. A space/place exists within its identity and is meaningless without it. Therefore, the construction of identity in the globalisation era can actually be seen as the preservation of the past identities of the space/place, so that spatial ideology values always remain within historical and socio-political dialectics. The sustainability of space/place identity can never be cut off from the ideological chains belonging to its constructor(s). It also determines the sustainability of the region's development. In the end, identity no longer becomes the representative function of the three parties' interests: government, society, and (neo) liberal economic actors.

\section{References}

Ashworth GJ (2009) The instrument of place branding. How is It Done? European Spatial Research and Policy, 16 (1):9-22.

Arnawa IGBL (1998) Mengenal Peninggalan Majapahit di Daerah Trowulan. Penerbit Koperasi Pegawai Republik Indonesia Purbakala Trowulan. [Accessed 3 March 2016]. https:// id.wikipedia.org/wiki/Gapura_Bajang_Ratu.

Banyuwangi.org [Accessed 29 May 2016]. http://banyuwangi.org/wp-content/uploads/2015/09/ Desain-Rumah-Mojopahit-Museum-Trowulan.jpg.

Bappeda.Jatim.go.id [Accessed 27 Juny 2016]. http://bappeda.jatimprov.go.id/2014/01/08/sbymuseum-mojopahit-trowulan-jadi-inspirasi-kebesaran-indonesia/.

Boisen M, Terlouw K \& Gorp BV (2011) The Selective Nature Of Place Branding. [Accessed 30 August 2016]. http://home.kpn.nl/C.Terlouw5/The\%20selective\%20nature\%20of\%20 place\%20branding.pdf.

Castells M (2009) Power of Identity: Economy, Society, and Culture (2nd Edition). USA: WileyBlackwell.

Castells M (2010) Globalisation and Identity, Quaderns de la Mediterrània 14, p.89-98.[Accessed 20 April 2018]. http://www.iemed.org/publicacions/quaderns/14/qm14_pdf/15.pdf.

Cresswell T (2004) Place: A Short Introduction. Oxford: Blackwell. 
Detik.com. [Accessed 26 May 2016]. https://news.detik.com/berita-jawa-timur/d-2803426/desainrumah-kampung-majapahit-bersumber-dari-kitab-negarakertagama.

Fairbanks II, RP (2003) A theoretical primer on space. Critical Social Work, 4 (1). [Accessed 25 November 2016]. https://www1.uwindsor.ca/criticalsocialwork/a-theoretical-primer-onspace.

Graham B, Ashworth GJ \& Tunbridge JE (2000) A Geography of Heritage: Power, Culture and Economy. London: Routledge. [Accessed 24 March 2016]. https://www.questia.com/.../ageography-of-heritage.

Harvey D (1989) The Condition of Postmodernity. Oxford: Blackwell.

Kalandides A (2011) The problem with spatial identity: Revisiting the sense of place. Journal of Place Management and Development, 4 (1):28-39. [Accessed 26 August 2016]. https://doi. org/10.1108/17538331111117142.

Kavaratzis M \& Ashworth GJ (2007) Partners in coffeeshops,canals and commerce: Marketing the City of Amsterdam, 42 (1):16-25. In: M Riza, N Doratli, \& M Fasli. Procedia Social and Behavioral Sciences, 35:293-300.

Kavaratzis M \& Hatch MJ (2013) The dynamics of place brands: An identity-based approach to place branding theory. Journal Marketing Theory 13 (1):69-86. http://mtq.sagepub.com/ content/13/1/69. Diakses 27 Agustus 2016.

Kavaratzis M \& Kalandides A (2015) Rethinking the place brand: The interactional form ation of place brands and the role of participatory place branding. Journal Environment and Planning A, 47:1368-1382. [Accessed 27 August 2016]. http://mtq.sagepub.com/.

Kotler P \& Gertner D (2002) Country as a brand, product and beyond: A place marketing and brand management perspective. Journal of Brand Management, 9 (4-5):249-261.

Kominfo Jatim (2015) Trowulan Mojokerto tetap sebagai Cagar Budaya. [Accessed 15 August 2016]. https://www. kominfo.jatimprov.go.id/read/umum/43813, 3 Maret 2015.

Lefebvre H (1974) The Production of Space, terjemahan dari La Production de l'espace oleh Donald Nicholson Smith. Cambridge MA: Blackwell.

Lynch K (1960) The image of the city. Cambridge: MIT Press. In: M Riza, N Doratli, \& M Fasli (2012) Procedia-Social and Behavioral Sciences, 35:293-300.

Pap Á (2014) The relationship between the built cultural heritage and the local identity: Actor centred geographical analysis based on budapest case studies. Theses of the Ph.D Dissertation, University of Szeged: Faculty of Science and Informatics. [Accessed 15 March 2016]. http://doktori.bibl.u-szeged.hu/.../Pap_Agi_tézisfüzet\%2.

Peraturan Menteri Pekerjaan Umum dan Perumahan Rakyat No. 01/PRT/M Tahun 2015 tentang Bangunan Gedung Cagar Budaya yang Dilestarikan.

Peraturan Pemerintah No. 36 Tahun 2005 tentang Peraturan Pelaksaan Undang-Undang No. 28 Tahun 2002.

Perda No.9 Tahun 2012 tentang Rencana Tata Ruang Wilayah Kabupaten Mojokerto Tahun 20122032.

Prajnawrdhi TA, Karuppannan S, \& Sivam A (2014) Preserving Cultural Heritage of Denpasar: Local Community Perspectives. [Accessed 8 Juny 2016]. www.sciencedirect.com.

Proshansky HM (1978) The City and Self-Identity. Environment and Behavior, dikutip Isil Kaymaz, Department of Landscape Architecture, Ankara University, Ankara, Turkey, Urban Landscapes and Identity, Chapter 29. [Accessed 16 July 2016]. http://www. cdn. intechopen.com/.../InTech-Urban_landscape.

Sepe M (2010) Place identity and placemaker: Planning the urban sustainability. Journal of Urban Planning And Development, 136 (2). DOI: 10.1061/(ASCE)0733-9488, 136:2(139). [Accessed 15 Mei 2016].

Sindonews [Accessed 29 May 2016]. (https://nasional.sindonews.com/read/1014482/149/rumahmajapahit-akan-ditambah-1434684497). 
Stobbelaar DJ \& Pedroli B (2011) Perspectives on landscape identity: A conceptual challenge. Landscape Research, 36 (3):321-39. [Accessed 17 Juny 2017]. http://www/taudfonline. com/loi/clar20.

UU No. 2 Tahun 1992 tentang Benda Cagar Budaya.

UU No. 11 Tahun 2010 tentang Cagar Budaya.

Vela JSE (2013) Place branding: A conceptual and theoretical framework. Boletin de la Asociacion de Geografos Espanoles, (62):189-211 dan 467-471. http://repositori.uvic.cat/ handle/10854/2295.

Wang RWC (2015) Culture Heritage and Identity: Some cases in Taiwan on the Protection of Cultural Heritage: The International Archives of the Photogrammetry. Remote Sensing and Spatial Information Sciences, XL-5/W7, 2015, 25th International CIPA Symposium 2015, 31 August - 04 September 2015, Taipei, Taiwan. [Accessed 25 April 2016]. www.int-archphotogramm-remote-sens-spatial-in.

Yuen B (2005) Strengthening urban heritage in Singapore: Building economic competitiveness and civic identity. Journal Global Urban Development, 1 (1). [Accessed 16 March 2016]. http:// www.globalurban.org/Issue1PIMag05/Yuen\%20article.htm.

Zhang L \& Zhao SX (2009) City Branding And The Olympic Effect: A Case Study of Beijing Cities, 25:245-254. [Accessed 24 Maret 2016]. http://www.elsevier.com/locate/cities.

Zenker S \& Jacobsen BP (eds) (2015) Inter-regional place branding: Best practices. Challenges and Solutions. Switzerland: Spinger. [Accessed 5 Mei 2016]. http://www.springer.com/la/ book/9783319153285. 